\title{
ANALISIS KELENGKAPAN IMUNISASI DASAR TERHADAP STATUS GIZI BALITA
}

\author{
Analysis Of Completeness Of Basic Immunization On Nutrition Status \\ For Toddler
}

Lilik Hanifah ${ }^{1}$ Ajeng Novita Sari ${ }^{2}$,

${ }^{1}$ STIKES Mamba’ul 'Ulum Surakarta ${ }^{2}$ Politeknik Santo Paulus Surakarta, Lilik_hanifah84@yahoo.com

\begin{abstract}
ABSTRAK
Latar Belakang : Imunisasi merupakan domain yang sangat penting untuk memiliki status gizi yang baik, dengan imunisasi seorang anak tidak mudah terserang penyakit yang berbahaya, sehingga anak lebih sehat, dengan tubuh/status sehat asupan makanan dapat masuk dengan baik, nutrisipun terserap dengan baik. Nutrisi yang terserap oleh tubuh balita dimanfaatkan untuk pertumbuhannya, sehingga menghasilkan status gizi yang baik.

Tujuan : Penelitian ini bertujuan untuk mengetahui hubungan kelengkapan imunisasi terhadap status gizi balita

Metode : Penelitian ini menggunakan metode deskriptif analitik dengan pendekatan cross sectional. Populasi dalam penelitian ini adalah semua balita yang datang untuk melakukan imunisasi di PMB Siti Maryam pada bulan Juli Desember 2020. Teknik sampling yang digunakan adalah Purposive Sampling, dimana sampel dalam penelitian ini adalah balita usia $18-24$ bulan yang datang untuk melakukan imunisasi di PMB Siti Maryam yang telah lulus imunisasi pada bulan Juli - Desember 2020 sebanyak 47 balita. Alat pengumpulan data menggunakan data rekam medis imunisasi balita. Analisis data menggunakan $C h i$ Square dengan Stastitical Product Servise Solution (SPSS) versi 26.

Hasil penelitian : sebagian besar kelengkapan imunisasi dasar balita dengan kategori lengkap sebanyak 40 responden $(85,1 \%)$. sebagian besar balita dengan status gizi normal sebanyak 41 responden $(87,2 \%)$. Berdasarkan hasil uji chi square di lihat dari nilai $\mathrm{p}$ sebesar 0,000 dan nilai taraf signifikansi 0,05 maka dapat diketahui bahwa nilai $\mathrm{p}<0,05(0,040<0,05)$, sehingga ada hubungan yang signifikan antara kelengkapan imunisasi dasar dengan status gizi balita.

Simpulan : ada hubungan yang signifikan antara kelengkapan imunisasi dasar dengan status gizi balita.
\end{abstract}

Kata kunci : Kelengkapan Imunisasi Dasar, Status Gizi, Balita 


\begin{abstract}
Background: Immunization is a very important domain for having a good nutritional status, with immunization a child is not susceptible to dangerous diseases, so that the child is healthier, with a healthy body / status, food intake can enter properly, even the nutrients are well absorbed. The nutrients absorbed by the toddler's body are utilized for their growth, resulting in a good nutritional status.

The aim : This study aims to determine the relationship between the completeness of immunization on the nutritional status of Toddler

Method: This study used a descriptive analytic method with a cross sectional approach. The population in this study were all toddlers who came to immunize at PMB Siti Maryam in July - December 2020. The sampling technique used was purposive sampling, where the sample in this study were toddlers aged 18-24 months who came to immunize at PMB Siti Maryam who had passed immunization in July - December 2020 as many as 47 toddlers. The data collection tool used immunization medical record data for children. Data analysis used Chi Square with Statistical Product Service Solution (SPSS) version 26.

Result: Most of the completeness of basic immunization for Toddler with complete categories were 40 respondents (85.1\%). Most of Toddler with normal nutritional status were 41 respondents $(87.2 \%)$. Based on the results of the chi-square test, it can be seen from the $p$ value of 0.000 and the significance level of 0.05 , it can be seen that the $p$ value $<0.05(0.040<0.05)$, so that there is a significant relationship between the completeness of basic immunization with the nutritional status of Toddler
\end{abstract}

Conclusion: There is a significant relationship between completeness of basic immunization and nutritional status of Toddler.

Keywords: Completeness of Basic Immunization, Nutritional Status, Toddler

\title{
PENDAHULUAN
}

Imunisasi selalu dikaitkan dengan angka kesakitan dan kematian pada bayi. Hal ini dikarenakan pemberian imunisasi adalah sebagai upaya untuk meningkatkan daya tahan tubuh terhadap berbagai penyakit. Berdasarkan tingkat frekuensi beberapa penyakit yang sering terjadi di Indonesia adalah Diphteria, Hepatitis B, Measles, Pertusis, Polio, Tetanus, Tetanus Neonatorum dan Tubercolosis. Imunisasi merupakan investasi hidup jangka pendek dan jangka panjang, sehingga keberhasilan pelaksanaan program imunisasi dapat terevaluasi dan menurunkan angka kesakitan, kecacatan dan kematian bayi sedangkan untuk jangka panjang dapat dilihat dan kualitas generasi muda dimasa mendatang selama perkembangannya (Lisnawati, 2011).

Imunisasi merupakan salah satu cara pencegahan penyakit menular khususnya Penyakit Yang Dapat Dicegah Dengan Imunisasi (PD3I) yang diberikan kepada tidak hanya anak sejak masih bayi hingga remaja tetapi juga 
kepada dewasa. Cara kerja imunisasi dengan memberikan antigen bakteri atau virus tertentu yang sudah dilemahkan atau dimatikan dengan tujuan merangsang sistem imun tubuh untuk membentuk antibodi. Antibodi yang terbentuk setelah imunisasi berguna untuk menimbulkan/meningkatkan kekebalan seseorang secara aktif sehingga dapat mencegah atau mengurangi akibat penularan PD3I (Rivanica, 2020).

Cakupan imunisasi dasar lengkap di Indonesia pada tahun 2016 sebesar 91,58\%. Angka ini mencapai target Renstra tahun 2016 sebesar 91,5\% (Kemenkes RI, 2017). Pada tahun 2017 cakupan imunisasi dasar lengkapmengalami penurunan yaitu 85,41\% (Kemenkes RI, 2018). Pada tahun 2018 cakupan imunisasi dasar lengkap juga mengalami penurunan dari tahun 2017 yaitu 57,95\% (Riskesdas, 2018).

Pemenuhan gizi pada anak usia dibawah lima tahun (balita) perlu diperhatikan untuk menjaga kesehatan, karena masa balita merupakan periode perkembangan yang rentan dengan gizi. Kasus kematian yang terjadi pada balita merupakan salah satu akibat dari gizi buruk. Gizi buruk dimulai dari penurunan berat badan ideal seorang anak sampai akhirnya terlihat sangat buruk. Indeks antropometri berat badan menurut umur $(\mathrm{BB} / \mathrm{U})$ merupakan penilaian status gizi yang paling sering digunakan karena lebih mudah dan lebih cepat dimengerti oleh masyarakat umum. Indeks antropometri berat badan menurut umur (BB/U) baik untuk mengatur status gizi akut/kronis dan dapat mendeteksi kegemukan (over weight) karena sangat sensitif terhadap perubahan-perubahan kecil. Indeks antropometri berat badan menurut umur (BB/U) mengklasifikasikan status gizi balita ke dalam gizi buruk, gizi kurang, gizi baik dan gizi lebih (Budianita, 2015).

Imunisasi merupakan domain yang sangat penting untuk memiliki status gizi yang baik. Imunisasi yang lengkap biasanya menghasilkan status gizi yang baik. Sebagai contoh adalah dengan imunisasi seorang anak tidak mudah terserang penyakit yang berbahaya, sehingga anak lebih sehat, dengan tubuh/status sehat asupan makanan dapat masuk dengan baik, nutrisipun terserap dengan baik. Nutrisi yang terserap oleh tubuh balita dimanfaatkan untuk pertumbuhannya, sehingga menghasilkan status gizi yang baik. (Vindriana, 2012).

Penelitian ini didukung oleh penelitian (Vindriana, 2012) dimana hasil penelitian menyatakan terdapat hubungan yang bermakna antara kelengkapan imunisasi, status kesehatan dengan status gizi. Semakin lengkap imunisasi, semakin baik status kesehatan sehingga status gizi juga cenderung lebih baik.

Penelitian sejenis juga dilakukan oleh (Ratifah, 2015) dimana analisis data menggunakan chi square dengan hasil bahwa status soasial ekonomi berhubungan signifikan dengan status gizi balita $(\mathrm{p}=0,006)$. Pengetahuan ibu berhubungan signifikan dengan status gizi balita $(\mathrm{p}=0,000)$. Pendidikan ibu berhubungan signifikan dengan status gizi balita $(\mathrm{p}=0,006)$. ASI eksklusif berhubungan signifikan dengan status gizi balita $(\mathrm{p}=0,013)$. Kelengkapan imunisasi berhubungan signifikan dengan status gizi balita $(\mathrm{p}=0,045)$.

Berdasarkan uraian diatas maka perlu dilakukan penelitian tentang kajian kelengkapan imunisasi dasar terhadap status gizi balita, sebagai upaya untuk meningkatkan derajat kesehatan bayi dan balita. 


\section{METODE PENELITIAN}

Penelitian ini menggunakan metode deskriptif dengan pendekatan cross sectional. Populasi dalam penelitian ini adalah semua balita yang datang untuk melakukan imunisasi di PMB Siti Maryam pada bulan Juli - Desember 2020. Teknik sampling yang digunakan adalah Purposive Sampling, dimana Sampel dalam penelitian ini adalah balita usia 18 - 24 bulan yang datang untuk melakukan imunisasi di PMB Siti Maryam yang telah lulus imunisasi pada bulan Juli Desember 2020 sebanyak 47 balita. Alat pengumpulan data menggunakan data rekam medis imunisasi balita. Analisis data menggunakan Chi Square dengan Stastitical Product Servise Solution (SPSS) versi 26.

\section{HASIL DAN PEMBAHASAN}

\section{Hasil}

1. Kelengkapan Imunisasi Dasar

Tabel 1 Distribusi frekuensi Kelengkapan Imunisasi Dasar

\begin{tabular}{llcc}
\hline No & $\begin{array}{c}\text { Kelengkapan } \\
\text { Imunisasi Dasar }\end{array}$ & Frekuensi & Prosentase(\%) \\
\hline 1 & Lengkap & 40 & 85,1 \\
2 & Tidak Lengkap & 7 & 14,9 \\
& Jumlah & 47 & 100 \\
\hline
\end{tabular}

Sumber: Data primer 2021

Berdasarkan tabel di atas sebagian besar responden kelengkapan imunisasi dasar dengan kategori lengkap sebanyak 40 responden $(85,1 \%)$.

2. Status Gizi Balita

Tabel 2 Distribusi frekuensi Status Gizi Balita

\begin{tabular}{llcc}
\hline No & Status Gizi Balita & Frekuensi & Prosentase $(\%)$ \\
\hline 1 & Normal & 41 & 87,2 \\
2 & Tidak Normal & 6 & 12,8 \\
& Jumlah & 47 & 100 \\
\hline
\end{tabular}

Sumber: Data primer 2021

Berdasarkan tabel di atas sebagian besar responden dengan Status Gizi Normal sebanyak 41 responden $(87,2 \%)$. 
3. Analisis Data Kelengkapan Imunisasi Dasar Terhadap Status Gizi Balita

Tabel 3. Analisis Kelengkapan Imunisasi Dasar Terhadap Status Gizi Balita

\begin{tabular}{|c|c|c|c|c|c|c|c|}
\hline \multirow{3}{*}{$\begin{array}{l}\text { Kelengkapan } \\
\text { Imunisasi }\end{array}$} & \multicolumn{4}{|c|}{ Status Gizi Balita } & \multirow[t]{3}{*}{ Total } & \multirow[t]{3}{*}{$\%$} & \multirow[t]{3}{*}{ Analisis Chi Square } \\
\hline & \multicolumn{2}{|c|}{ Normal } & \multicolumn{2}{|c|}{ Tidak Normal } & & & \\
\hline & & $\%$ & & $\%$ & & & \\
\hline Lengkap & 37 & 90,2 & 3 & 50 & 40 & 85,1 & Significant 0,000 \\
\hline Tidak Lengkap & 4 & 9,8 & 3 & 50 & 7 & 14,9 & Contingency \\
\hline Jumlah & 41 & 100 & 6 & 100 & 47 & 100 & Coefficient 0.730 \\
\hline
\end{tabular}

Sumber: Data primer 2021

Pada Tabel di atas menunjukkan mayoritas responden memiliki kelengkapan imunisasi dengan kategori lengkap dan status gizi normal yaitu sebanyak 37 responden $(90,2 \%)$. Berdasarkan hasil uji chi - square di lihat dari nilai p sebesar 0,000 dan nilai taraf signifikansi 0,05 maka dapat diketahui bahwa nilai $p<0,05$ $(0,040<0,05)$, sehingga kesimpulannya ada hubungan yang signifikan antara kelengkapan imunisasi dasar dengan status gizi balita. dan nilai Contingency Coefficient 0.730 sehingga hubungannya kuat

\section{Pembahasan}

Dari hasil penelitian diperoleh hasil bahwa mayoritas kelengkapan imunisasi balita dengan kategori lengkap dan status gizi normal. Sedangkan berdasarkan analisa data diketahui bahwa ada hubungan yang signifikan antara kelengkapan imunisasi dasar dengan status gizi balita, dimana nilai Contingency Coefficient 0.730 sehingga hubungannya kuat

Imunisasi merupakan domain yang sangat penting untuk memiliki status gizi yang baik. Imunisasi yang lengkap biasanya menghasilkan status gizi yang baik. Sebagai contoh adalah dengan imunisasi seorang anak tidak mudah terserang penyakit yang berbahaya, sehingga anak lebih sehat, dengan tubuh/status sehat asupan makanan dapat masuk dengan baik, nutrisipun terserap dengan baik. Nutrisi yang terserap oleh tubuh balita dimanfaatkan untuk pertumbuhannya, sehingga menghasilkan status gizi yang baik. (Vindriana, 2012).

Penelitian ini didukung oleh penelitian (Vindriana, 2012) dimana hasil penelitian menyatakan terdapat hubungan yang bermakna antara kelengkapan imunisasi, status kesehatan dengan status gizi. Semakin lengkap imunisasi, semakin baik status kesehatan sehingga status gizi juga cenderung lebih baik.

Penelitian sejenis juga dilakukan oleh (Ratifah, 2015) dimana analisis data menggunakan chi square dengan hasil bahwa status soasial ekonomi berhubungan signifikan dengan status gizi balita $(\mathrm{p}=0,006)$. Pengetahuan ibu berhubungan signifikan dengan status gizi balita $(\mathrm{p}=0,000)$. Pendidikan ibu berhubungan signifikan dengan status gizi balita $(\mathrm{p}=0,006)$. ASI eksklusif berhubungan signifikan dengan status gizi balita $(p=0,013)$. Kelengkapan imunisasi berhubungan signifikan dengan status gizi balita $(\mathrm{p}=0,045)$.

Berdasarkan hasil penelitian menunjukkan bahwa ada hubungan antara pemberian imunisasi dasar dengan pertumbuhan pada bayi (0-1 tahun). Hal ini 
didasarkan pada hasil analisis yang diperoleh dari Uji chi square menunjukkan bahwa nilai $p$ value $0,046=a(0,05)$. Perhitungan risk estimate diperoleh nilai odd ratio $(O R)=0,188$, sehingga dapat disimpulkan bahwa responden dengan imunisasi tidak lengkap memiliki risiko 0,188 kali pada pertumbuhan bayi dibandingkan dengan imunisasi lengkap.

Berdasarkan hasil penelitian, peneliti berpendapat bahwa imunisasi merupakan bagian yang penting untuk memiliki pertumbuhan yang baik, dengan imunisasi dasar lengkap biasanya bayi menghasilkan pertumbuhan yang baik. Sebagai contoh dengan imunisasi seorang bayi rentan terhadap penyakit yang berbahaya, sedangkan bayi yang tidak memiliki kekebalan tubuh akan mudah terkena penyakit infeksi tertentu. Hal ini dikarenakan fungsi kekebalan yang saling berhubungan erat satu sama lain dan pada akhirnya akan mempengaruhi pertumbuhan berupa status gizi pada bayi (Prasetya, 2019).

Penelitian ini sejalan dengan penelitian dari Hikmah (2016) yang menyatakan didapatkan hasil uji chi-square imunisasi dengan pertumbuhan didapatkan hasil analisa $\mathrm{p}=0,000<0,05$ ) maka dapat disimpulkan Ha diterima yang artinya ada hubungan antara pemberian imunisasi dengan pertumbuhan. hasil analisis diperoleh nilai $\mathrm{OR}=7.000$ artinya todler yang mendapatkan imunisasi lengkap mempunyai peluang 7 kali untuk mendapatkan pertumbuhan yang normal dibandingkan dengan todler yang tidak mendapatkan imunisasi lengkap.

Hal ini juga sesuai dengan teori yang menyatakan bahwa toddler yang sehat akan memiliki tumbuh kembang yang baik sedangkan todler yang sakit akan terganggu pula tumbuh kembangnya. Tumbuh kembang yang baik didapatkan apabila anak mendapatkan dan diberikan imunisasi yang lengkap, gizi yang baik, pola pengasuhan orang tua dan lingkungan pengasuhan yang baik (Kementerian Kesehatan, 2014).

\section{SIMPULAN DAN SARAN}

\section{Simpulan}

sebagian besar kelengkapan imunisasi dasar balita dengan kategori lengkap sebanyak 40 responden $(85,1 \%)$. sebagian besar balita dengan status gizi normal sebanyak 41 responden $(87,2 \%)$. Berdasarkan hasil uji chi - square di lihat dari nilai p sebesar 0,000 dan nilai taraf signifikansi 0,05 maka dapat diketahui bahwa nilai $\mathrm{p}<0,05(0,040<0,05)$, sehingga ada hubungan yang signifikan antara kelengkapan imunisasi dasar dengan status gizi balita.

\section{Saran}

Diharapkan Ibu balita untuk memperhatikan kelengkapan imunisasi dasar pada anaknya dan datang sesuai jadwal imunisasi yang telah ditentukan, sehingga dapat dipantau juga status gizinya Peneliti selanjutnya diharapkan dapat meneliti tentang faktor - faktor yang mempengaruhi status gizi balita seperti pendidikan ibu, umur ibu, sosial ekonomi, genetik, dll. STIKES Mamba'ul 'Ulum Surakarta juga diharapkan untuk rutin mengikutsertakan civitas akademik dalam kegiatan penyuluhan tentang pentingnya kelengkapan imunisasi dasar dan status gizi balita 


\section{DAFTAR PUSTAKA}

Budianita, E dan Novriyanto. 2015. Klasifikasi Status Gizi Balita Berdasarkan Indikator Antropometri Berat Badan Menurut Umur Menggunakan Learning Vector Quantization. Seminar Nasional Teknologi Informasi, Komunikasi dan Industri (SNTIKI) 7. ISSN :2085-9902 Pekanbaru, 11 November 2015

Hikmah, Yanti.R, Yuri.W. 2016. Hubungan Kelengkapan Imunisasi Dasar Dengan Tumbuh Kembang Toddler Di Posyandu Bunga Padi Kota Tangerang. Jurnal JKFT Universitas Muhammadiyah Tangerang, Edisi Nomor 2, Januari 2016 (89 - 96)

Kemenkes RI. (2017). Profil kesehatan Indonesia Tahun 2016. Jakarta: Kementrian Kesehatan RI.

Kemenkes RI. (2018). Profil Kesehatan Indonesia Tahun 2017. Jakarta: Kementrian Kesehatan RI.

Kemenkes RI. 2015. Buku Ajar Imunisasi, Cetakan II. Jakarta: Pusdiklatnakes.

Kemenkes RI. 2013. Modul pelatihan Imuniasi bagi Petugas Puskesmas.Jakarta: Direktorat Simkar dan Kesma, Ditjen PP dan PL.

Kementerian Kesehatan. (2014). Pedoman Pelaksanaan Stimulasi, Deteksi dan Intervensi Dini Tumbuh Kembang Anak Ditingkat Pelayanan Kesehatan Dasar: Jakarta

Lisnawati, L. 2011. Generasi Sehat Melalui Imunisasi. Jakarta : CV. Trans Info Medika

Prasetya, S.O. 2019. Hubungan Pemberian Imunisasi Dasar Dengan Tumbuh Kembang Bayi (0-1 Tahun). Jurnal Kesehatan Vol 10. No 2 Tahun 2019. LP3M STIKes Cirebon. DOI: http://dx.doi.org/10.38165/jk. e-ISSN: 27219518 p-ISSN: 2088-0278

Ratifah, Supadi, Mulida.S. 2015. Faktor - faktor yang Berhubungan dengan Status Gizi Balita. LINK Vol.11 No. 1 Januari 2015 ISSN 1829-5754

Riskesdas. (2018). Hasil Utama Riskesdas 2018. Jakarta: Kementrian Kesehatan RI.

Rivanicha, R dan Hartina, I. 2020. Pemberian Imunisasi BCG Pada Bayi (1-3 Bulan) Berdasarkan Tingkat Pengetahuan Dan Sikap Ibu. Jurnal 'Aisyiah Medika Volume 5, Nomor 1, Februari 2020.

Vindriana V, Kadir A, Askar M, 2012. Hubungan Kelengkapan Imunisasi Dengan Status Gizi Pada Balita Usia 1-5 Tahun Di Kelurahan Watonea Wilayah Kerja Puskesmas Katobu Kabupaten Muna. Jurnal Ilmiah Kesehatan Diagnosis. Volume 1 Nomor 2 Tahun 2012. ISSN : 2302-1721 